\title{
Légköri nukleáció és következményei
}

\author{
SALMA Imre ${ }^{\mathrm{a},{ }^{*}}$ NÉMETH Zoltán ${ }^{\mathrm{a}}$, VARGA Veronika ${ }^{\mathrm{a}}$ és WEIDINGER Tamás ${ }^{\mathrm{b}}$ \\ ${ }^{a}$ ELTE Kémiai Intézet, Pázmány Péter stny. 1/A, 1117 Budapest, Magyarország \\ ${ }^{b}$ ELTE Meteorológiai Tanszék, Pázmány Péter stny. 1/A, 1117 Budapest, Magyarország
}

\section{Bevezetés}

A Budapest Aeroszol Kutató és Oktató Platform (BpART, http://salma.web.elte.hu/BpArt) 5. éve sikeresen müködik. ${ }^{1}$ Fő céljai között szerepel a levegőkörnyezetre vonatkozó tudományos ismeretek megszerzése és bővítése. A kutatási irányok az aeroszol keletkezését, kémiai és fizikai tulajdonságait, illetve folyamatait, valamint az egészségügyi, éghajlati és környezeti hatásaikat egyaránt magukba foglalják. A BpART az ELTE Kémiai Intézetének önálló kutatólaboratóriumává vált, és bekapcsolódott a klímaadaptív és fenntartható hazai mezőgazdaságot szolgáló, multidiszciplináris kutatóműhely (AGROMO) munkájába is. Emellett helyszínül szolgál nemzetközi tudományos együttmüködések számára. Az elért eredményeknek sajátos alkalmazása a Budapest levegőminőségére vonatkozó háttér-információk és értékelések készítése az érintett, fővárosi referensek/döntést előkészítők számára. Az elmúlt évek egyik legfontosabb kutatási témájává a légköri nukleáció és következményeinek tanulmányozása vált. Jelen beszámolóban ezen, szükebb területen elért, újabb tudományos eredményeinket és következtetéseinket foglaljuk össze tömören.

\section{Légköri nukleáció}

A légköri nukleáció olyan elsőrendű fázisátalakulás, amely során légnemű anyagokból (pl. $\mathrm{SO}_{2}$, illékony szerves vegyületek, VOC) fotokémiai oxidációt követően kisebb gőznyomású, kondenzációra képes gőzök keletkeznek (pl. $\mathrm{H}_{2} \mathrm{SO}_{4}$, extrém kis illékonyságú VOC-k), amelyek a légkörben jelenlévő más anyagokkal (pl. $\mathrm{H}_{2} \mathrm{O}, \mathrm{NH}_{3}$ ) új, szilárd vagy folyékony fázist - azaz aeroszol rendszert eredményeznek. ${ }^{2}$ A nukleáción kívül más folyamatokban is keletkezhetnek részecskék, például magas hőmérsékletü emissziós folyamatokban (gépjármüvek kipufogógáza vagy háztartási tüzelés). Ezek tipikus terméke a korom aeroszol vagy a kátránygömb. Az aprózódásból (pl. szélerózióból vagy tengeri permettel) keletkező részecskék száma elhanyagolható az előző csoportokhoz képest. Nagyon fontos különbség, hogy az elsődleges részecskék a forrásban történő kondenzációs folyamatok miatt általában nagyobbak a nukleációs részecskéknél. Az újonnan formálódó, nukleációs részecskék mérete mintegy $2 \mathrm{~nm},{ }^{3}$ míg az elsődleges részecskék mérete $20-100$ nm körüli. ${ }^{4}$

A légköri nukleációt eleinte tisztább, távoli vagy erdős környezetekben figyelték meg, és azt gondolták, hogy a szennyezett, például városi levegőben kis valószínűséggel valósul csak meg. ${ }^{5}$ Később bebizonyosodott, hogy a folyamatot a kondenzációra képes gőzök forrásainak és nyelőinek aránya vezérli, így nagy nyelő értéknél (pl. szennyezett levegő) is lehetséges, ha a források erőssége még nagyobb.

\subsection{Mechanizmus}

Gázmolekulák véletlenszerű ütközésével különféle molekulaklaszterek jönnek létre a légkörben. Ezek a klaszterek egy idő után szétesnek. A klasztereket alkotó molekulák közötti kémiai kölcsönhatások bizonyos esetekben azonban megnövelik a klaszterek élettartamát, ami túltelítettség esetén stabilis részecskékhez vezethet. Ha a molekulaklaszter mérete ugyanis elér egy kritikus méretet $(1.7 \pm 0.5 \mathrm{~nm})^{3}$, akkor energetikai és kinetikai szempontból is lehetővé és előnyössé válik a klaszter spontán növekedése. Ezáltal a homogén fázisból új, diszpergált formában megjelenő, heterogén fázis, vagyis új aeroszol részecskék keletkeznek. A fázisátalakulást követően a részecskék tekintettel a meglévő túltelítettségre - kondenzációval tovább növekedhetnek. A folyamat elején a növekedési sebességet a részecske és a molekulák közötti ütközések határozzák meg, míg később a folyamat hajtóereje a molekuláris diffúzió lesz, és a növekedés lelassul.

Kezdetben úgy gondolták, hogy a kénsavmolekula jelenléte elengedhetetlen az újrészecske-képződéshez a keveredési határrétegben jellemző koncentráció- és hőmérsékleti viszonyok között, és a kénsav-ammónia-vízgőz ternális nukleáció tünt valószínűnek. ${ }^{6}$ Később ködkamra kísérletekben kimutatták, hogy az említett rendszer nem elégséges a légkörben megfigyelt keletkezési sebességek értelmezéséhez, és más alkotók (pl. aminok) ${ }^{7}$ hozzájárulása is szükséges, amelyek akár négy nagyságrenddel is megnövelik a nukleáció sebességét. Sikerült továbbá meghatározni a biogén (föleg növényi) eredetű VOC-k oxidációs termékeinek szerepét, illetve ezen oxidált termékeket azonosították a légkörben frissen nukleálódott részecskékben. ${ }^{8}$ Kimutatták továbbá, hogy a biogén eredetü gázok (pl. $\alpha$-pinén) oxidációs termékei - amelyeket nagymértékben oxidálódott molekuláknak (HOM-nak, highly oxygenated molecules) nevezünk - képesek új részecskéket létrehozni kénsav nélkül is. ${ }^{7} \mathrm{Az}$ újabb elképzelések $^{9,10}$ szerint a részecskék növekedésében kezdetben - a Kelvin-hatásnak köszönhetően - csak a kevésbé illékony HOM-ok játszanak szerepet, míg a részecskeméret növekedésével az illékonyabb HOM-ok is jelentőssé válnak. Az új aeroszol részecskék keletkezésére

*Tel.: +1 372-26-15; E-mail: salma@chem.elte.hu

125. évfolyam, 2. szám, 2019. 
több folyamat és a helyi meteorológiai helyzet is hatással van. Kedvező feltételek például az elővegyületek nagy koncentrációja, az erős napsugárzás és kis relatív páratartalom, illetve ha kicsi a rendelkezésre álló felület a versengő kondenzációs nyelő számára.

\subsection{Jelentőség}

Légköri nukleációt szinte minden jelentős környezetben megfigyeltek a troposzférában. ${ }^{11}$ A nukleáció eredményezi az aeroszol részecskék számának döntő részét a globális légkörben. ${ }^{12}$ Ezen túlmenően, az így keletkezett aeroszol részecskék növekedésével felhőkondenzációs magvak (Cloud Condensation Nuclei, CCN) jönnek létre, amelyek elengedhetetlen szereplői a felhőcseppek kialakulásának. ${ }^{13}$ Tiszta levegőben csak több száz százalékos túltelítettségnél alakul ki felhöcsepp, ám ilyen körülmények a légkörben még a felhők belsejében sem léteznek. Felhőkondenzációs magvak jelenlétében már sokkal kisebb mértékű vízgőz túltelítettség is elegendő a felhőcseppek képződéséhez. A Föld légkörében globálisan és átlagosan lényegében állandónak tekinthető a vízgőz mennyisége, viszont az aeroszol részecskeszám-koncentráció változhat. Ha kevesebb részecske van a légkörben, akkor általában kevesebb számú, de nagyobb méretü cseppek keletkeznek, amelyek kevésbé szórják a napsugárzást. Szennyezettebb levegőben az azonos mennyiségü vízpára több részecskére kondenzálódik, így nagyobb számú, de kisebb méretü csepp keletkezik. Ezek összfelülete nagyobb, így nagyobb mértékben szórják a napfényt. Az ilyen felhőknek nagyobb az albedója, és légköri tartózkodási idejük is megnő. Söt, nagyobb CCN koncentráció esetén előfordul, hogy a felhőcseppek nem tudnak elég nagyra nőni ahhoz, hogy csapadékként távozzanak a légkörből. Az aeroszol részecskék tehát a csapadékképződésben is szerepet játszanak. A kevesebb csapadékmennyiség és az egyenetlen csapadékeloszlás súlyos természeti, gazdasági és mezőgazdasági károkat okozhat. A CCN-ek mintegy fele légköri nukleációból származik, ${ }^{13}$ ami az aeroszol képződést összekapcsolja az éghajlatváltozás témakörével. Az éghajlati modellek legnagyobb egyedi bizonytalanságát jelenleg a felhőkhöz kapcsolódó ismeretek hiánya jelenti.

Az emberi szervezet leginkább a tüdőn keresztül érintkezik a környezettel. Az oldható aeroszol részecskék kiülepedésük után elveszítik eredeti alakjukat és fizikai tulajdonságaikat. Az általuk kiváltott biológiai választ tömegük és kémiai összetételük határozza meg leginkább. Az oldhatatlan részecskék azonban a depozíció után is megtartják alakjukat és fizikai tulajdonságaikat, esetükben felületi tulajdonságaik és számuk határozza meg a biológiai választ. Oldhatatlan részecskék tisztulása a tüdőből hónapokig, évekig is eltarthat. Az utóbbi években kimutatták, hogy az ultrafinom (UF) részecskék $(d<100 \mathrm{~nm})$ többlet egészségügyi hatással rendelkeznek a hasonló kémiai összetételü, finom és durva részecskékhez képest. Ennek oka a kis méret, a nagy részecskeszám-koncentráció és a nagy fajlagos felület, ami nagyobb biológiai aktivitást eredményezhet. ${ }^{14} \mathrm{~A}$ nanorészecskék $(d<10 \mathrm{~nm})$ kedvezőtlen hatása nem csak a tüdőben, hanem azon kívül is érvényesülhet, mert a hidrofób/lipofil entitások a tüdő hámján átjutva transzlokálódhatnak más szervekbe (pl. máj, központi idegrendszer), és ott fejthetik ki hatásukat. ${ }^{15}$

\section{Módszerek}

A légköri nukleáció tanulmányozása a részecskeszám méreteloszlás folyamatos, hosszú időn keresztül végzett mérésével megvalósítható. ${ }^{16}$ A méréseket az aeroszol részecskék differenciális elektromos mozgékonyságán alapuló, részecskeméret szeparátorral (Differential Mobility Particle Sizer, DMPS) végezzük. ${ }^{17}$ A módszerrel a 6-1000 nm átméröjü részecskék méreteloszlását mérjük 30 csatornában, körülbelül 8 perc időfelbontással. (1. ábra) A mérések 7. éve nappal és éjjel munkanapokon és munkaszüneti napokon zajlanak. A teljes mérési évek a következők voltak: 1.: 2008. 11. 03-2009. 11. 02., 2.: 2012. 01. 19-2013. 01. 18., 3.: 2013. 11. 13-2014. 11. 12., 4.: 2014. 11. 13-2015. 11. 12., 5.: 2015. 11.13-2016. 11. 12. és 6.: 2017. 01. 28-2018. 01. 27. A 2. mérési évet egy városközeli háttérhelyen (Csillebércen) valósítottuk meg, míg a többi mérés a belvárosban történt. A napok mérési lefedettsége éves szinten rendre a következő volt: 95\%, 95\%, $99 \%, 95 \%, 73 \%$ és $99 \%$. A méréseket azóta is folytatjuk. A kialakult, hosszú adatsor teszi lehetővé a levegőkémiai ismeretek megszerzését kiterjedt kiértékelési és modellezési számolások segítségével, amelyek az újrészecske-képződés azonosítását, az előfordulási gyakoriság meghatározását, a keletkezési és növekedési sebességek, időparaméterek kiszámolását, a fő nyelök és a nukleációs erősségi tényező megállapítását, valamint a koncentrációk, illetve a méreteloszlások és a források közötti kapcsolatrendszer feltárását foglalják magukba.

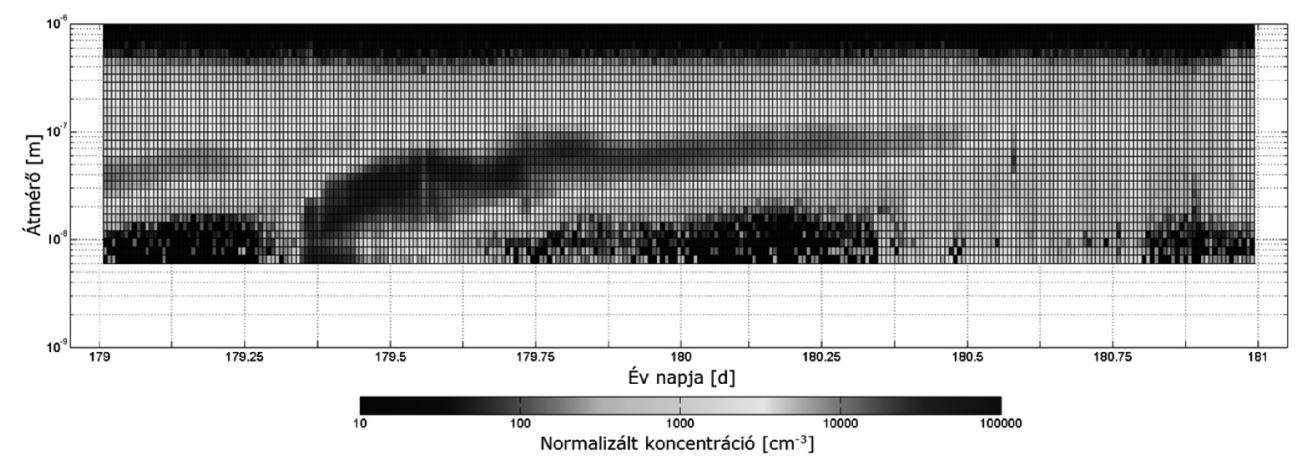

1. Ábra. A légköri nukleáció és részecske növekedés által létrehozott tipikus banángörbe Budapesten. 


\section{Eredmények és követeztetések}

$\mathrm{Az}$ aeroszol részecskék éves medián koncentrációja $11,5 \times 10^{3} ; 9,7 \times 10^{3} ; 9,3 \times 10^{3} ; 7,3 \times 10^{3}$ és $10,6 \times 10^{3} \mathrm{~cm}^{-3}$ volt az említett, 5 év során a belvárosban, míg a városközeli háttérkörnyezetben $3,9 \times 10^{3} \mathrm{~cm}^{-3}$ medián értéket kaptunk. A részecskék közel 85\%-a az UF méretfrakcióba tartozott a belvárosban.

\subsection{Gyakoriság}

A nukleáció előfordulásának gyakoriságát a 2. ábrán tüntettük fel. Az éves gyakoriság 13,0\% és 28\% között változott $22 \%$ középértékkel. Ez azt jelenti, hogy éves skálán minden 4-5. napon történik nukleáció Budapesten. A különbségeket az évek közötti, elsősorban meteorológiai változékonyság okozta. A havi eloszlás hasonló menetet mutatott mindegyik évben. Az újrészecske-képződésnek januárban abszolút minimuma, augusztusban lokális minimuma, míg márciusban vagy áprilisban abszolút maximuma, illetve szeptemberben lokális maximuma volt. Ennek magyarázata multifaktoriális okokra vezethető vissza, amelyek közül kiemelhetö a biogén emisszió hatása, ami az élő természet éves ciklusához kapcsolódik.

\section{Hónap}

Dec Jan Feb Már Ápr Máj Jún Júl Aug Szep Okt Nov
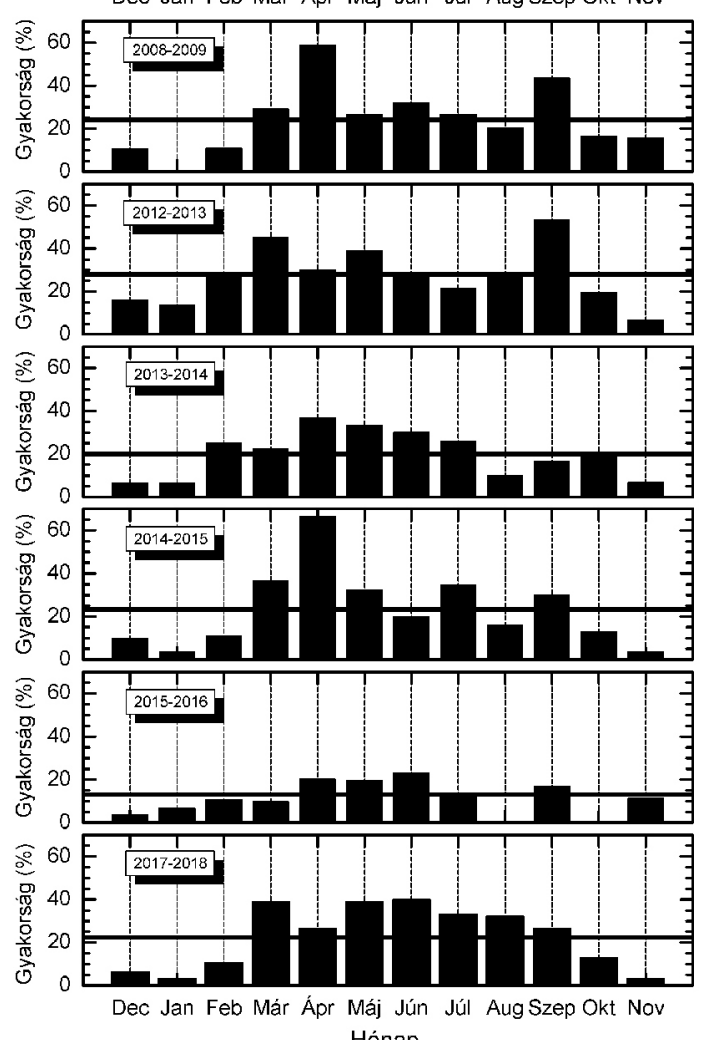

Hónap

2. Ábra. A légköri nukleáció havi relatív gyakoriságának eloszlása Budapesten az egyes mérési években.

\subsection{Dinamikai tulajdonságok}

Nukleáció következtében a 6 nm átmérőjü részecskék keletkezési sebessége a belvárosban 0,81 és $24 \mathrm{~cm}^{-3} \mathrm{~s}^{-1}$ között változott $5,6 \pm 3,8 \mathrm{~cm}^{-3} \mathrm{~s}^{-1}$ középértékkel és szórással, míg a kapcsolódó értékek a városközeli háttérkörnyezetben rendre
$0,48-5,6 \mathrm{~cm}^{-3} \mathrm{~s}^{-1}$ és $2,2 \pm 1,3 \mathrm{~cm}^{-3} \mathrm{~s}^{-1}$ voltak. A $10 \mathrm{~nm}$ átmérőjü részecskék közepes növekedési sebessége és szórása $7,6 \pm 2,9 \mathrm{~nm} \mathrm{~h}^{-1}$ volt a belvárosban, és $5,2 \pm 1,4 \mathrm{~nm} \mathrm{~h}^{-1}$ a város

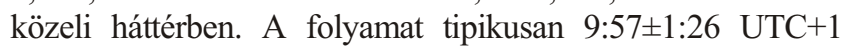
órakor kezdődött a belvárosban, és kb. 1 órával korábban indult a városi háttérhelyen. A belvárosban megtalálható légköri kémiai anyagok azonos mértékben járultak hozzá a részecskék keletkezéséhez és a növekedéséhez, míg a városi háttérben lévő specieszek jobban segítik a növekedést, mint a keletkezést. Eredményeinket más közép-európai városok adataival együtt is értelmeztük. ${ }^{18}$

\subsection{Következmények}

A statisztikai módszerek, a növekedési görbék vizsgálata, a visszaszámolt légcella trajektóriák és a koincidencia analízis együttesen azt mutatják, hogy 1) a légköri nukleáció horizontális kiterjedése összemérhető a Karpát-medence méretével, ${ }^{19}$ 2) a nukleáció térben koherens módon jön létre egy konzisztens, nagyobb méretü légköri jelenég megnyilvánulásaként. ${ }^{20} \mathrm{Mindez}$ nem jelenti azonban azt, hogy a nukleáció azonos időben jelentkezik mindenhol és térben azonos (izotróp) módon valósul meg, mert a folyamat feltételeinek meglétét rendszeres vagy véletlen változások jelentősen módosíthatják vagy megszüntethetik azt (pl. a túltelítettségen keresztül). Meghatároztuk továbbá, hogy nukleációs napokon - amikor kisebb a kondenzációs nyelő, tehát viszonylag tiszta a levegő - a részecskék száma közel kétszeresére nő a nukleáció következtében a korábbihoz képest, míg szennyezettebb napokon kisebb valószínüséggel történik nukleáció. ${ }^{21}$ Mindez a napi átlagos részecskeszám- koncentrációk kisebb változékonyságát eredményezi, ami teljesen eltér a részecskék tömeg-koncentrációjának időváltozásától. Az aeroszol részecskék közel 28\%-át eredményezi a légköri nukleáció a belvárosban hosszabb (legalább éves) időskálán, míg a külvárosban a járulék elérheti a 34\%-ot. ${ }^{22}$ Mindez azt mutatja, hogy a jelenség meglehetösen nagy relevanciával rendelkezik nemcsak az éghajat szempontjából - beleértve a városklíma alakulását -, de fontos következménye van a városlakók egészségére is. Kísérletileg meghatározott aeroszol tulajdonságok és sztochasztikus matematikai tüdőmodell segítségével megbecsültük, hogy a belélegzett részecskék számának közel fele kiülepedik a légzőszervekben. ${ }^{23}$ Az arány kevéssé függ a városi környezettől és a fizikai igénybevételtől. A kiülepedett részecskék több, mint fele az acináris (a légcserét lebonyolító) tüdőrégióba kerül, és az arányuk 50\%-ról 75\%-ra nö a fizikai igénybevétellel. Ezek az értékek meglehetősen nagyok a részecskék által képviselt tömeg tüdőbeli kiülepedésével (legfeljebb mintegy 15\%) összehasonlítva. Legnagyobb felületi kiülepedési sebesség a mellkason kívüli részben (például az orrban) alakul ki. Mindez egyrészt különleges kockázatot jelent a szaglószervek sajátosságai miatt, másrészt azonban jelentős potenciált teremt a központi idegrendszer nanométer méretü részecskékből álló inhalációs gyógyszerekkel történő kezelésére.

\section{Köszönetnyilvánítás}

A kutatómunkát a Nemzeti Kutatási, Fejlesztési és Innovációs Hivatal (a K116788 és a PD124283 szerződések alapján), valamint a Széchenyi 2020 program, Magyarország Kormánya és az Európai Regionális Fejlesztési Alap (GINOP-2.3.2-15-2016-00028 és GINOP-2.3.2.15-2016-00055 szerződések alapján) támogatta. 


\section{Hivatkozások}

1. Salma, I., Németh, Z., Weidinger, T., Kovács, B., Kristóf, G. Atmos. Chem. Phys. 2016, 16, 7837-7851, https://doi.org/10.5194/acp-16-7837-2016

2. Kulmala, M., Riipinen, I., Sipilä, M., Manninen, H. E., Petäjä, T., Junninen, H., Dal Maso, M., Mordas, G., Mirme, A., Vana, M., Hirsikko, A., Laakso, L., Harrison, R. M., Hanson, I., Leung, C., Lehtinen, K. E. J., Kerminen, V.-M. Science 2007, 318, 89-92,

https://doi.org/10.1126/science.1144124

3. Kulmala, M., Kontkanen, J., Junninen, H., Lehtipalo, K., Manninen, H. E., Nieminen, T., Petäjä, T., Sipilä, M., Schobesberger, S., Rantala, P., Franchin, A., Jokinen, T., Järvinen, E., Äijälä, M., Kangasluoma, J., Hakala, J., Aalto, P. P., Paasonen, P., Mikkilä, J., Vanhanen, J., Aalto, J., Hakola, H., Makkonen, U., Ruuskanen, T., Mauldin III, R. L., Duplissy, J., Vehkamäki, H., Bäck, J., Kortelainen, A., Riipinen, I., Kurtén, T., Johnston, M. V., Smith, J. N., Ehn, M., Mentel, T. F., Lehtinen, K. E. J., Laaksonen, A., Kerminen, V.-M., Worsnop, D. R. Science 2013, 339, 943-946, https://doi.org/10.1126/science. 1227385

4. Shi, J. P., Harrison, R. M. Environ. Sci. Technol. 1999, 33, 3730-3736, https://doi.org/10.1021/es9811871

5. Kulmala, M., Vehkamäki, H., Petäjä, T., Dal Maso, M., Lauri, A., Kerminen, V.-M., Birmili, W., McMurry, P. J. Aerosol Sci. 2004, 35, 143-176, https://doi.org/10.1016/j.jaerosci.2003.10.003

6. Kirkby, J., Curtius, J., Almeida, J., Dunne, E., Duplissy, J., Ehrhart, S., Franchin, A., Gagne, S., Ickes, L., Kürten, A., Kupc, A., Metzger, A., Riccobono, F., Rondo, L., Schobesberger, S., Tsagkogeorgas, G., Wimmer, D., Amorim, A., Bianchi, F., Breitenlechner, M., David, A., Dommen, J., Downard, A., Ehn, M., Flagan, R. C., Haider, S., Hansel, A., Hauser, D., Jud, W., Junninen, H., Kreissl, F., Kvashin, A., Laaksonen, A., Lehtipalo, K., Lima, J., Lovejoy, E. R., Makhmutov, V., Mathot, S., Mikkilä, J., Minginette, P., Mogo, S., Nieminen, T., Onnela, A., Pereira, P., Petäjä, T., Schnitzhofer, R., Seinfeld, J. H., Sipilä, M., Stozhkov, Y., Stratmann, F., Tome, A., Vanhanen, J., Viisanen, Y., Vrtala, A., Wagner, P. E., Walther, H., Weingartner, E., Wex, H., Winkler, P. M., Carslaw, K. S., Worsnop, D. R., Baltensperger, U., Kulmala, M. Nature 2011, 476, 429-433, https://doi.org/10.1038/nature10343

7. Almeida, J., Schobesberger, S., Kürten, A., Ortega, I. K., Kupiainen-Maatta, O., Praplan, A. P., Adamov, A., Amorim, A., Bianchi, F., Breitenlechner, M., David, A., Dommen, J., Donahue, N. M., Downard, A., Dunne, E., Duplissy, J., Ehrhart, S., Flagan, R. C., Franchin, A., Guida, R., Hakala, J., Hansel, A., Heinritzi, M., Henschel, H., Jokinen, T., Junninen, H., Kajos, M., Kangasluoma, J., Keskinen, H., Kupc, A., Kurten, T., Kvashin, A. N., Laaksonen, A., Lehtipalo, K., Leiminger, M., Leppa, J., Loukonen, V., Makhmutov, V., Mathot, S., McGrath, M. J., Nieminen, T., Olenius, T., Onnela, A., Petäjä, T., Riccobono, F., Riipinen, I., Rissanen, M., Rondo, L., Ruuskanen, T., Santos, F. D., Sarnela, N., Schallhart, S., Schnitzhofer, R., Seinfeld, J. H., Simon, M., Sipilä, M., Stozhkov, Y., Stratmann, F., Tome, A., Tröstl, J., Tsagkogeorgas, G., Vaattovaara, P., Viisanen, Y., Virtanen, A., Vrtala, A., Wagner, P. E., Weingartner, E., Wex, H., Williamson, C., Wimmer, D., Ye, P. L., Yli-Juuti, T., Carslaw, K. S., Kulmala, M., Curtius, J., Baltensperger, U., Worsnop, D. R., Vehkamäki, H., Kirkby, J. Nature 2013, 502, 359-363, https://doi.org/10.1038/nature12663
8. Riccobono, F., Schobesberger, S., Scott, C. E., Dommen, J., Ortega, I. K., Rondo, L., Almeida, J., Amorim, A., Bianchi, F., Breitenlechner, M., David, A., Downard, A., Dunne, E. M., Duplissy, J., Ehrhart, S., Flagan, R. C., Franchin, A., Hansel, A., Junninen, H., Kajos, M., Keskinen, H., Kupc, A., Kürten, A., Kvashin, A. N., Laaksonen, A., Lehtipalo, K., Makhmutov, V., Mathot, S., Nieminen, T., Onnela, A., Petäjä, T., Praplan, A. P., Santos, F. D., Schallhart, S., Seinfeld, J. H., Sipilä, M., Spracklen, D. V., Stozhkov, Y., Stratmann, F., Tome, A., Tsagkogeorgas, G., Vaattovaara, P., Viisanen, Y., Vrtala, A., Wagner, P. E., Weingartner, E., Wex, H., Wimmer, D., Carslaw, K. S., Curtius, J., Donahue, N. M., Kirkby, J., Kulmala, M., Worsnop, D. R., Baltensperger, U. Science 2014, 344, 717-721, https://doi.org/10.1126/science.1243527

9. Bianchi, F., Tröstl, J., Junninen, H., Frege, C., Henne, S., Hoyle, C. R., Molteni, U., Herrmann, E., Adamov, A., Bukowiecki, N., Chen, X., Duplissy, J., Gysel, M., Hutterli, M., Kangasluoma, J., Kontkanen, J., Kürten, A., Manninen, H. E., Münch, S., Peräkylä, O., Petäjä, T., Rondo, L., Williamson, C., Weingartner, E., Curtius, J., Worsnop, D. R., Kulmala, M., Dommen, J., Baltensperger, U. Science 2016, 352, 1109-1112, https://doi.org/10.1126/science.aad5456

10. Tröstl, J., Chuang, W. K., Gordon, H., Heinritzi, M., Yan, C., Molteni, U., Ahlm, L., Frege, C., Bianchi, F., Wagner, R., Simon, M., Lehtipalo, K., Williamson, C., Craven, J. S., Duplissy, J., Adamov, A., Almeida, J., Bernhammer, A.-K., Breitenlechner, M., Brilke, S., Dias, A., Ehrhart, S., Flagan, R. C., Franchin, A., Fuchs, C., Guida, R., Gysel, M., Hansel, A., Hoyle, C. R., Jokinen, T., Junninen, H., Kangasluoma, J., Keskinen, H., Kim, J., Krapf, M., Kürten, A., Laaksonen, A., Lawler, M., Leiminger, M., Mathot, S., Möhler, O., Nieminen, T., Onnela, A., Petäjä, T., Piel, F. M., Miettinen, P., Rissanen, M. P., Rondo, L., Sarnela, N., Schobesberger, S., Sengupta, K., Sipilä, M., Smith, J. N., Steiner, G., Tomč, A., Virtanen, A., Wagner, A. C., Weingartner, E., Wimmer, D., Winkler, P. M., Ye, P., Carslaw, K. S., Curtius, J., Dommen, J., Kirkby, J., Kulmala, M., Riipinen, I., Worsnop, D. R., Donahue, N. M., Baltensperger, U. Nature 2016, 533, 527-531, https://doi.org/10.1038/nature18271

11. Nieminen, T., Kerminen, V.-M., Petäjä, T., Manninen, H. E., Aalto, P. P., Arshinov, M., Asmi, E., Baltensberger, U., Beukes, J. P., Collins, D., Harrison, R. M., Henzing, B., Hooda, R., Hu, M., Hőrrak, U., Kivekäs, N., Komsaare, K., Krejčí, R., Laakso, L., Laaksonen, A., Leaitch, R., Lihavainen, H., Mihalopoulos, N., Németh, Z., O’Dowd, C., Salma, I., Sellegri, K., Svenningsson, B., Swietlicki, E., Tunved, P., Ulevicius, V., Vakkari, V., Vana, M., Virtanen, A., Wiedensohler, A., Kulmala, M. Atmos. Chem. Phys. Discuss., 2018, 18, 14737-14756, https://doi.org/10.5194/acp-18-14737-2018

12. Spracklen, D. V., Carslaw, K. S., Merikanto, J., Mann, G. W., Reddington, C. L., Pickering, S., Ogren, J. A., Andrews, E., Baltensperger, U., Weingartner, E., Boy, M., Kulmala. M., Laakso, L., Lihavainen, H., Kivekas, N., Komppula, M., Mihalopoulos, N., Kouvarakis, G., Jennings, S. G., O’Dowd, C., Birmili, W., Wiedensohler, A., Weller, R., Gras, J., Laj, P., Sellegri, K., Bonn, B., Krejčí, R., Laaksonen, A., Hamed, A., Minikin, A., Harrison, R. M., Talbot, R., Sun, J. Atmos. Chem. Phys. 2006, 6, 5631-5648, https://doi.org/10.5194/acp-6-5631-2006

13. Merikanto, J., Spracklen, D. V., Mann, G. W., Pickering, S. J., Carslaw, K. S. Atmos. Chem. Phys. 2009, 9, 8601-8616, https://doi.org/10.5194/acp-9-8601-2009 
14. Oberdörster, G., Oberdörster, E., Oberdörster, J. Environ. Health Perspect., 2005, 113, 823-839, https://doi.org/10.1289/ehp.7339

15. Braakhuis, H. M., Park, M. V., Gosens, I., De Jong, W. H., Cassee, F. R. Part. Fibre Toxicol. 2014, 11:18, https://doi.org/10.1186/1743-8977-11-18

16. Kulmala, M., Petäjä, T., Nieminen, T., Sipilä, M., Manninen, H. E., Lehtipalo, K., Dal Maso, M., Aalto, P. P., Junninen, H., Paasonen, P., Riipinen, I., Lehtinen, K. E. J., Laaksonen, A., Kerminen, V.-M. Nat. Protoc., 2012, 7, 1651-1667, https://doi.org/10.1038/nprot.2012.091

17. Salma, I., Borsós, T., Weidinger, T., Aalto, P., Hussein, T., Dal Maso, M., Kulmala, M., Atmos. Chem. Phys. 2011, 11, 1339-1353, https://doi.org/10.5194/acp-11-1339-2011

18. Németh, Z., Rosati, B., Zíková, N., Salma, I., Bozó, L., Dameto de Espańa, C., Schwarz, J., Ždímal, V., Wonaschütz, A. Atmos. Environ. 2018, 178, 191-197, https://doi.org/10.1016/j.atmosenv.2018.01.035

\section{Atmospheric nucleation and its consequences}

New aerosol particle formation (NPF) and consecutive particle growth processes in the atmosphere were first identified in clean environments, and their occurrence frequency and contribution to particle number concentrations were later found to be substantial in the global troposphere. Particles originating from these processes affect the Earth's radiation balance mainly by acting as cloud condensation nuclei $(\mathrm{CCN})$, and their contribution to the total number of $\mathrm{CCN}$ can be up to $50 \%$ or even more. Recently, NPF has been proved to be common in polluted environments, including large cities as well.

Particle number size distributions were measured by a Differential Mobility Particle Sizer (DMPS) in the diameter range of 6-1000 $\mathrm{nm}$ with a time resolution of ca. $8 \mathrm{~min}$ for several years. The measurements were carried out in the city centre for 5 years, and in the near-city background of Budapest for 1 year. The median total particle number concentrations were $11.5 \times 10^{3}, 9.7 \times 10^{3}, 9.3 \times 10^{3}, 7.3 \times 10^{3}$ and $10.6 \times 10^{3} \mathrm{~cm}^{-3}$ in the city centre for 5 years, respectively. They showed slightly decreasing tendency during the years except the last year. The ultrafine (UF) ratio had a similar, decreasing tendency pattern, resulted by the alteration of new particle formation frequency and the fluctuation of other anthropogenic sources. In the near-city background, the median total particle number concentration was $3.9 \times 10^{3}$ $\mathrm{cm}^{-3}$, and the UF contribution to the total concentration was $66 \%$ due to the lower traffic and local emission sources. The annual mean nucleation frequencies were $24 \%, 20 \%, 23 \%$, $13 \%$, and $23 \%$ for the 5 years in the city centre, and $27 \%$ in the near-city background. The mean occurrence of NPF was the highest in spring and high in autumn, which is in line with previous measurements in urban environments. It was caused by favourable meteorological conditions as well. The annual global maximum of NPF occurrence coincided with the lowest monthly mean RH values during 3 out of the 5 years. The spring peak was associated with the first month in the year which had higher mean temperature than the annual mean temperature. Formation rate at a particle diameter of 6 $\mathrm{nm}$ varied from 0.81 to $24 \mathrm{~cm}^{-3} \mathrm{~s}^{-1}$ with a mean and standard
19. Németh, Z., Salma, I. Atmos. Chem. Phys. 2014, 14, 8841-8848, https://doi.org/10.5194/acp-14-8841-2014

20. Salma, I., Németh, Z., Kerminen, V-M., Aalto, P., Nieminen, T., Weidinger, T., Molnár, Á., Imre, K., Kulmala, M. Atmos. Chem. Phys. 2016, 16, 8715-8728, https://doi.org/10.5194/acp-16-8715-2016

21. Salma, I., Borsós, T., Németh, Z., Weidinger, T., Aalto, P., Kulmala, M. Atmos. Environ. 2014, 92, 154-161, https://doi.org/10.1016/j.atmosenv.2014.04.020

22. Salma, I., Varga, V., Németh, Z. Atmos. Chem. Phys. 2017, 17, 15007-15017, https://doi.org/10.5194/acp-17-15007-2017

23. Salma, I., Füri, P., Németh, Z., Farkas, Á., Balásházy, I., Hofmann, W., Farkas, Á. Atmos. Environ. 2015, 104, 39-49, http://dx.doi.org/10.1016/j.atmosenv.2014.12.060

deviation (SD) of $5.6 \pm 3.8 \mathrm{~cm}^{-3} \mathrm{~s}^{-1}$ in the city centre, while the same properties for the near-city background were 0.48-5.6 $\mathrm{cm}^{-3} \mathrm{~s}^{-1}$, and $2.2 \pm 1.3 \mathrm{~cm}^{-3} \mathrm{~s}^{-1}$, respectively. The mean particle growth rate with SDs for 10-nm particles were 7.6 $\pm 2.9 \mathrm{~nm}$ $\mathrm{h}^{-1}$ in the city centre, and $5.2 \pm 1.4 \mathrm{~nm} \mathrm{~h}^{-1}$ in the near city background. The mean starting time of the nucleation and its SD were 9:57 $\pm 1: 26 \mathrm{UTC}+1$, and it was delayed by about 1 hour with respect to the near-city background. These data revealed some similarities and differences in the NPF process itself between the city centre and near-city background atmospheric environments.

We investigate further the effect of regional NPF on urban aerosol load under well-defined atmospheric conditions. The Carpathian Basin, the largest orogenic basin in Europe, represents an excellent opportunity for exploring these interactions. We revealed that NPF seen in a central large city of the basin (Budapest) and its regional background occur in a consistent and spatially coherent way as a result of a joint atmospheric phenomenon taking place over large horizontal scales. We found that NPF events at the urban site are usually delayed by 1 hour relative to the rural site or even inhibited above a critical condensational sink level.

The effects of NPF and particle diameter growth process as a single source on atmospheric particle number concentrations were evaluated and quantified on the basis of long-term experimental data sets obtained from particle number size distribution measurements. Nucleation strength factors separately for a nucleation day and for a general day were derived for seasons and full years. The former characteristics represents the concentration increment of UF particles specifically on nucleation days with respect to accumulation mode (regional background) concentration (particles with equivalent diameters of $\left.100-1000 \mathrm{~nm} ; N_{100-1000}\right)$ due solely to nucleation process. The latter factor expresses the contribution of nucleation to particle numbers on general days, thus it represents a longer time interval such as season or year. The nucleation source had the largest effect on the concentrations around noon and early afternoon as expected. During this time interval, it became the major source of 
particles in the near-city background. Nucleation increased the daily mean concentrations on nucleation days by mean factors of 2.3 and 1.58 in the near-city background and city centre, respectively. Its effect was the largest in winter, which was explained with the substantially lower $N_{100-1000}$ levels on nucleation days than that on non-nucleation days. On an annual time scale, $34 \%$ of the UF particles were generated by nucleation in the near-city background, while NPF produced $28 \%$ of UF particles in the city centre. The differences among the annual mean values, and among the corresponding seasonal mean values were likely caused by the variability in controlling factors from year to year. The shares determined imply that NPF is a non-negligible or substantial source of particles in near-city background environments and even in city centres, where the vehicular road emissions usually prevail.
Realistic median particle number size distributions were utilized to derive the deposition of inhaled particles within airway generations of an adult woman by a stochastic lung deposition model for sleeping, sitting, light and heavy exercise breathing conditions. Deposition fractions in the respiratory tract were considerable and constant for all physical activities with a mean of $56 \%$. The mean deposition fraction in the acinar region averaged for the urban locations increased monotonically with physical activity from $14.7 \%$ for sleeping to $34 \%$ for heavy exercise. The largest contribution of the acinar deposition to the lung deposition was $75 \%$. The deposition rates in the lung were larger than in the extra-thoracic region, and the deposition rate in the lung was increasingly realised in the acinar region by physical activity. It was the extra-thoracic region that received the largest surface density deposition rates; its loading was higher by 3 orders of magnitude than for the lung. 